\title{
Knockdown of long noncoding RNA CCAT1 inhibits cell growth, invasion and peritoneal metastasis via downregulation of Bmi-1 in gastric cancer
}

\author{
N. LI", K. JIANG \\ Department of Medical Oncology, The Second Affiliated Hospital of Dalian Medical University, Dalian 116023, People’s Republic of China \\ ${ }^{*}$ Correspondence: $y u z h e d a l i a n @ 163 . c o m$ \\ \#Contributed equally to this work.
}

Received December 6, 2017 / Accepted February 28, 2018

\begin{abstract}
Long noncoding RNA colon cancer-associated transcript 1 (lncRNA CCAT1) is highly expressed in gastric cancer (GC) tissues compared to normal counterparts and CCAT1 up-regulation promotes proliferation and migration of GC cells in vitro. B-cell specific moloney leukemia virus insertion site 1 (Bmi-1) expression positively correlates with tumor progression. This study investigates the biological functions of CCAT1 and the relationships between CCAT1 and Bmi-1 in GC progression. Herein, CCAT1 was knocked down by specific shRNA transfection in two human GC cell lines (MGC-803 and SGC-7901) and the effects of this knockdown on GC cell proliferation, cell cycle migration and invasion were investigated in vitro. The effect of CCAT1 knockdown on peritoneal metastasis was assessed in nude mice, and Bmi-1 expression levels were examined both in vitro and in vivo. The results showed that Bmi-1 down-regulation and CCAT1 knockdown markedly inhibit cell proliferation, migration and invasion, arrests the cell cycle in the G0/G1 phase in vitro and inhibit peritoneal metastasis in nude mice. The combined results establish that CCAT1 is functionally involved in growth and metastasis of GC cells and it is therefore a potential target for GC therapy.
\end{abstract}

Key words: IncRNA CCAT1, Bmi-1, gastric cancer, RNA interference, peritoneal metastasis

Gastric cancer (GC) is the fourth most common malignancy and the second leading cause of global cancer-related deaths [1]. Numerous factors are associated with the progression of GC, including Helicobacter pylori infection, smoking, high salt intake and genetic factors [2]. The five-year survival rate is only $20 \%$ [3]. More than $70 \%$ of new cases are in developing countries and approximately $50 \%$ occur in eastern Asia, especially in China [4]. Most GC patients are diagnosed in the middle and late stages after lymph node or distant metastasis [5] and it is therefore imperative to determine metastasis mechanisms and identify potential therapeutic GC targets.

Long noncoding RNAs (lncRNAs) are non-proteincoding transcripts longer than 200 nucleotides [6], and increasing evidence demonstrates that lncRNAs have critical roles in cancer through RNA alternative splicing and decay, chromatin remodeling, X-chromosome imprinting, cell differentiation, metastasis and drug resistance $[7,8]$. Aberrant lncRNA expression has been reported in many cancers, including GC [9]. Colon cancer-associated transcript 1 (CCAT1), a recently discovered lncRNA located on chromosome $8 \mathrm{q} 24.21$ near c-Myc, is up-regulated in GC, colon cancer, hepatocellular carcinoma and cholangiocarcinoma compared to adjacent normal tissues [10-14]. Further, Yang et al. [15] also reported that CCAT1 promotes cell proliferation and migration in gastric carcinoma in vitro.

In contrast, CCAT1 knockdown inhibits proliferation, migration and epithelial-mesenchymal transition in vitro and suppresses tumor growth and progression in vivo in glioma [16]. However, the role of CCAT1 in distant metastasis in GC has not yet been documented. Therefore, CCAT1 was knocked down by specific shRNA herein, in order to investigate its role in GC cell proliferation, migration, invasion and peritoneal metastasis.

\section{Materials and methods}

Cell lines. Human GC cell lines MGC-803 and SGC-7901 were obtained from Zhong Qiao Xin Zhou Biotechnology Co., Ltd. (Shanghai, China). The cells were grown in RPMI-1640 (Gibco, Grand Island, New York, USA) with 10\% fetal bovine serum (FBS; HyClone, Logan, UT, USA) in a humidified 5\% $\mathrm{CO}_{2}$ incubator at $37^{\circ} \mathrm{C}$. 
shRNA synthesis, vector construction and transfection. The oligonucleotides targeting CCAT1 (shCCAT1) and scrambled control (NC) were synthesized by Sangon Biotech (Shanghai, China), with the following sequences: shCCAT1-sense, 5'-GATCCCCACACCGGATGGACATCAGATTCAAGAGATCTGATGTCCATCCGGTGTTTTTT-3' and shCCAT1 antisense, 5'-AGCTAA A A A A A C C G GA T G GA C A T C A GATC T C T T GAATCTGATGTCCATCCGGTGTGGG-3'; NC-sense, 5' - GA T C C C C T T C T C C GA A C G T G T C A C G T T T CAAGAGAACGTGACACGTTCGGAGAATTTTT-3' and NC-antisense, 5'-AGCTAAAAATTCTCCGAACGTGTCACGTTCTCTTGAAACGTGACACGTTCGGAGAAGGG-3'. The targeted sequence of shCCAT1 was 5'-ACACCGGAUGGACAUCAGA-3'.

The oligonucleotides were then cloned into interference vector pRNA-H1.1 (GenScript, Nanjing, China) and the recombinant plasmids were confirmed by DNA sequencing. The cells were grown in 6-well plates for 24 hours at $37^{\circ} \mathrm{C}$ and then transfected with $2 \mu \mathrm{g}$ of recombinant plasmid by Lipofectamine 2000 (Invitrogen, Carlsbad, CA, USA) according to manufacturer protocol. Cells transfected with pRNA-H1.1 containing scrambled control were used as negative controls. At 24 hours post-transfection, the stable transfectants were selected by treatment with selective agent G418 for two weeks $(700 \mu \mathrm{g} / \mathrm{ml}$ in RPMI-1640) (Invitrogen, USA). The in vitro knockdown efficiency was measured by reverse transcription-quantitative polymerase chain reaction (RT-qPCR).

RT-qPCR. Total RNAs, isolated from cells or peritoneal tumor tissues by RNApure Total RNA Extraction Kit (BioTeke, Beijing, China), were reverse-transcribed into cDNA using moloney murine leukemia virus (M-MLV) reverse transcriptase (BioTeke, China) RT-qPCR was then performed using SYBR Green I (Solarbio, Beijing, China) on the Exicycler ${ }^{\mathrm{Tm}} 96$ from Bioneer (Daejeon, Korea).

The primer sequences are: CCAT1-forward, 5'-ATTGGGAAAGGTGCCGAGA-3' and CCAT1-reverse, 5'-ACAGAGCCAACCTGGTAAGTG-3'; Bmi-1-forward, 5'-CAAATGCTGGAGAACTGGAAAG-3' and Bmi-1-reverse, 5'-TGGCAAAAGAAGATTGGTGG-3'; $\beta$-actin-forward, 5'CTTAGTTGCGTTACACCCTTTCTTG-3' and $\beta$-actin-reverse, 5'-CTGTCACCTTCACCGTTCCAGTTT-3'.

These primers were synthesized by Sangon Biotech (Shanghai, China), and RT-qPCR was performed in triplicate. $\beta$-actin served as internal control and relative expression levels were calculated by the $2^{-\Delta \Delta \mathrm{Ct}}$ method.

MTT assay. The cells were harvested by trypsinization, seeded onto 96 -well plates at $4 \times 10^{3}$ cells/well density and cultured at $37^{\circ} \mathrm{C}$ in a $5 \% \mathrm{CO}_{2}$ incubator. Then, $5 \mathrm{mg} / \mathrm{ml} \mathrm{MTT}$ (Sigma, Shanghai, China) was added to each well at 0,24 , 48,72 and 96 hours and the plates were incubated at $37^{\circ} \mathrm{C}$ for 4 hours. Supernatant was discarded, dimethyl sulfoxide (DMSO, $150 \mu \mathrm{l})$ (Sigma, China) was added to each well and optical density at 570nm was measured by Elx800 microplate reader from BioTek (Beijing, China).
Colony formation assay. The cells were seeded onto $35 \mathrm{~mm}$ Petri dish (200 cells/dish) and cultured at $37^{\circ} \mathrm{C}$ for approximately two weeks. Subsequently, the cells were washed twice with PBS and fixed with $4 \%$ paraformaldehyde at room temperature for $20 \mathrm{~min}$. After washing twice with PBS, the cells were stained with Wright-Giemsa stain (Nanjing Jiancheng Bioengineering Institute, Nanjing, China). Colonies larger than or equal to 50 cells were counted and colony formation rate was calculated by the following formula: Colony formation rate $(\%)=$ colony number/seeded cell number $\times 100 \%$.

Cell cycle detection by flow cytometry. The cells were washed twice with PBS and fixed with $70 \%$ ethanol for 2 hours at $4{ }^{\circ} \mathrm{C}$, and then incubated with $25 \mu \mathrm{l}$ propidium iodide (PI) (Beyotime, Haimen, China) and $10 \mu$ l RNase A (Beyotime, China) for 30 minutes at $37^{\circ} \mathrm{C}$ in the dark. Flow cytometric analysis was performed by Accuri C6 (BD Biosciences, San Jose, CA, USA).

Western blotting. Proteins were extracted from cells or peritoneal tumor tissues with RIPA lysis buffer (Beyotime, China), and BCA protein assay kit (Beyotime, China) determined the protein concentration. Equal $40 \mu \mathrm{g}$ amounts of protein were separated by 11 or $13 \%$ SDS-PAGE, transferred onto PVDF membranes (Millipore, Bedford, MA, USA) and incubated with the following; non-fat milk and primary antibodies against cyclin B (1:500 dilution; Bioss, Beijing, China), cyclin D1 (1:400 dilution; Boster, Wuhan, China), cyclin E (1:500 dilution; Bioss, China), Bmi-1 (1:500 dilution; Sangon, Shanghai, China) and $\beta$-actin (1:500 dilution; Bioss, China).

The membranes were then incubated with secondary antibody (1:5000 dilution; Beyotime, China) and the bands were visualized by enhanced chemiluminescence reagent (Beyotime, China). Finally, the band optical densities were analyzed by Gel-Pro Analyzer 4.0 software (Media Cybernetics, Rockville, MD, USA).

Wound healing assay. After confluence, the cells were cultured in serum-free RPMI-1640 medium containing $1 \mu \mathrm{g} / \mathrm{ml}$ mitomycin C (Sigma, China) for 1 hour at $37^{\circ} \mathrm{C}$ and then scratched by sterile pipette tip $(200 \mu \mathrm{l})$. Cell debris was removed by washing with serum-free RPMI-1640 medium and the cells were maintained in serum-free RPMI-1640 medium at $37^{\circ} \mathrm{C}$ for 12 and 24 hours. Images were then taken under an inverted microscope (Motic, Xiamen, China).

Transwell invasion assay. The cells $\left(1 \times 10^{4}\right)$ were resuspended in serum-free RPMI-1640 medium and added to the upper chamber of the Transwell insert $(8-\mu \mathrm{m}$ pore size polycarbonate membrane; Corning Incorporated, Corning, NY, USA) pre-coated with Matrigel (BD Biosciences, San Jose, CA, USA). RPMI-1640 medium containing 30\% FBS was added to the lower chamber as chemo-attractant. After 24 hour incubation at $37^{\circ} \mathrm{C}$, non-invaded cells were removed by cotton swabs and the invaded cells on the lower membrane surface were fixed in $4 \%$ paraformaldehyde for 20 minutes and stained with $0.5 \%$ crystal violet 
(AMRESCO LLC, Solon, OH, USA) for 5 minutes at room temperature. The number of invaded cells in five randomly selected regions was counted under an inverted microscope (Motic, China).

In vivo studies. Male BALB/c nude mice aged 5 weeks and weighing 16-18 g were obtained from Vital River (Beijing, China). These were raised under specific pathogen free (SPF) conditions with a 12 hour light/dark cycle and divided into $\mathrm{NC}$ and shCCAT1 groups ( $\mathrm{n}=6 \mathrm{mice} /$ group). The experi- ments were performed under the National Institute of Health guidelines for the care and use of laboratory animals and approved by the Animal Ethics Committee of Dalian Medical University. The nude mice were peritoneally injected with $200 \mu \mathrm{l}$ cell suspension at a density of $8 \times 10^{7}$ cells $/ \mathrm{ml}$. They were then sacrificed 35 days post-injection by overdosed pentobarbital sodium (100 mg/kg body weight) and the number of nodules in the mesentery and peritoneal walls were counted and photographed.

A
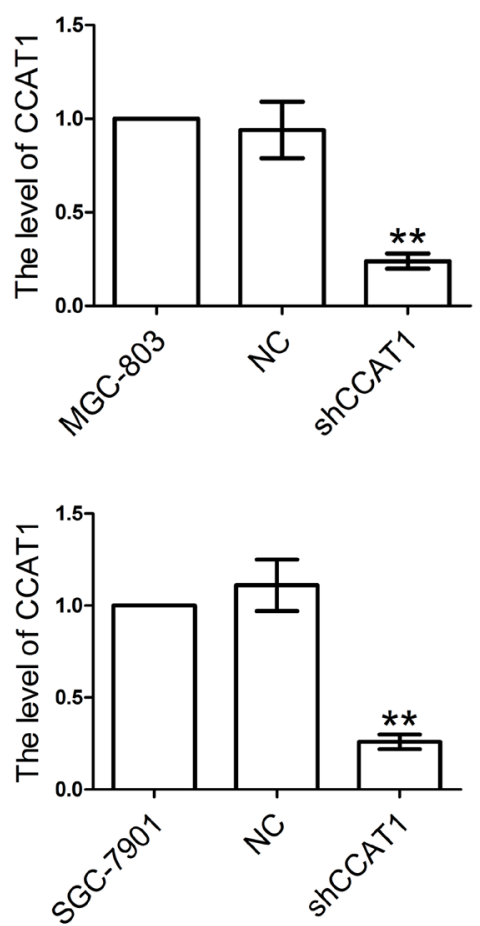

C

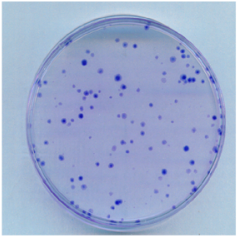

MGC-803

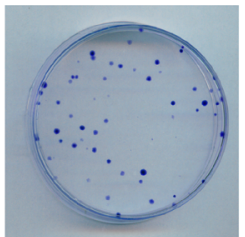

SGC-7901

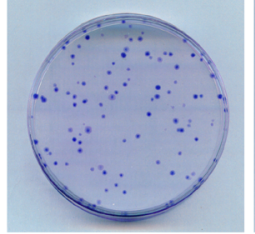

NC

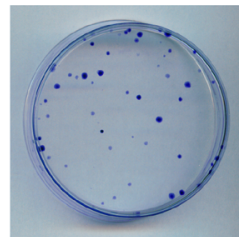

NC

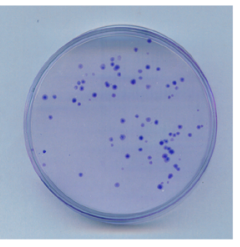

shCCAT1

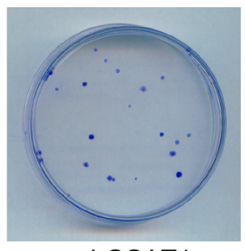

shCCAT1
B
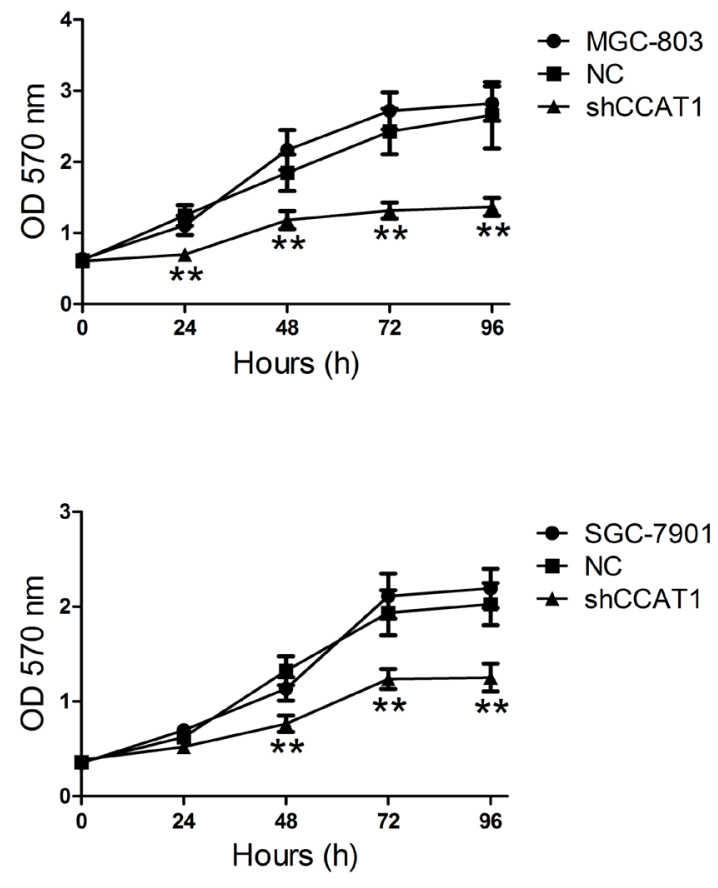

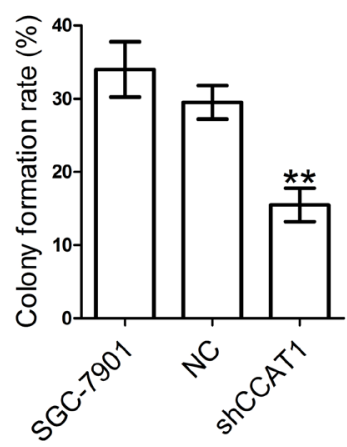

Figure 1. CCAT1 knockdown inhibits proliferation of GC cells. A) MGC-803 and SGC-7901 cells were transfected with CCAT1 shRNA or NC. After selection of stable transfectants, RT-qPCR was performed to analyze the level of CCAT1 $(n=3)$. B) MTT assay examined the viability of GC cell lines $(0$, $24,48,72$ and $96 \mathrm{~h})(\mathrm{n}=5)$. C) Colony formation ability was evaluated by colony formation assay $(\mathrm{n}=3)$, and data is presented as the mean \pm SD, $n=3$ or 5. $\mathrm{p}<0.05$ and ${ }^{* *} \mathrm{p}<0.01$ compared with the $\mathrm{NC}$ group. 
Statistical analysis. All values are presented as mean \pm SD, and differences between groups were determined by one-way ANOVA followed by Bonferroni post-hoc test or Student's $\mathrm{t}$-test. P-values less than 0.05 were statistically significant.

\section{Results}

CCAT1 knockdown inhibits GC cell proliferation. CCAT1 was knocked down in human MGC-803 and SGC-7901 GC cell lines by RNA interference (RNAi) in order to investigate the biological functions of CCAT1 in GC. Figure 1A shows that RT-qPCR-determined CCAT1 levels in both shCCAT1-transfected cell lines were significantly lower than those in the NC-transfected cells. Cell viability was then assessed by MTT assay and clonogenic capacity was evaluated by colony formation assay. The MTT results highlighted that cell viabilities in both cell lines of shCCAT1-transfected cells were obviously reduced compared to cells transfected with NC (MGC-803, at 24, 48, 72 and 96 hours and SGC-7901, at 48, 72 and 96 hours Figure 1B).

Colony formation assay determined that colony formation abilities of MGC-803 and SGC-7901 cells were significantly suppressed by shCCAT1 transfection (Figure 1C). Cell cycle distribution and proteins associated with the cell cycle were examined by flow cytometry and western blotting. The results showed that shCCAT1 transfection arrested the cell cycle in the G0/G1 phase (Figure 2A) and consequently

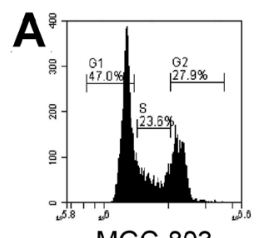

MGC-803

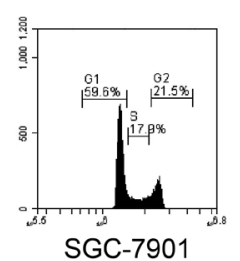

B
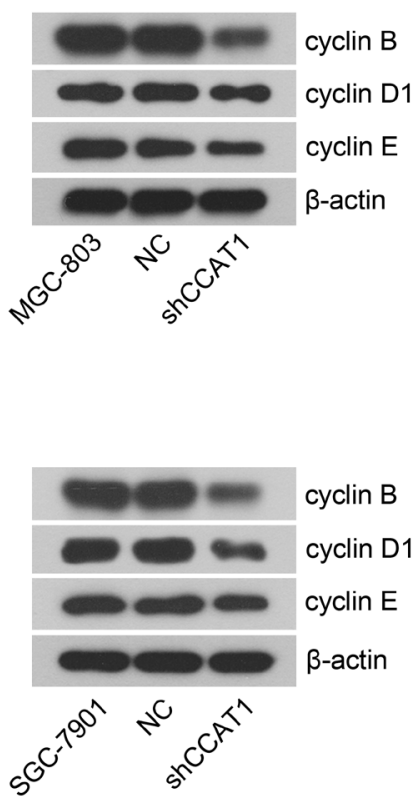
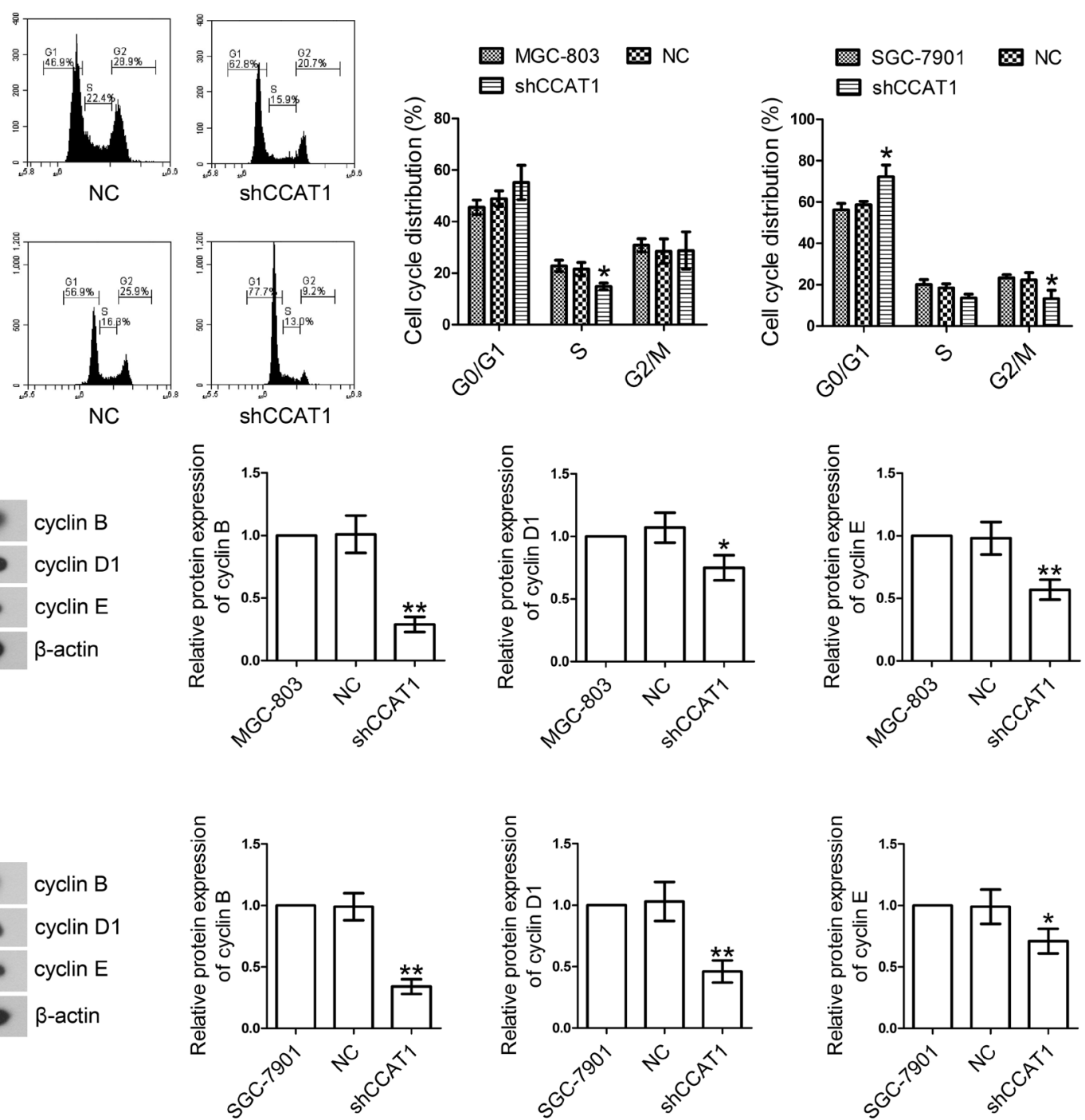

Figure 2. CCAT1 knockdown arrests the cell cycle at G0/G1 phase. A) Cell cycle distribution was determined by flow cytometry. B) Cell cycle-related proteins (cyclin B, cyclin D1 and cyclin E) were examined by western blotting and $\beta$-actin served as internal control. Data is presented as the mean \pm SD, $n=3$. ${ }^{*} \mathbf{p}<0.05$ and ${ }^{* *} \mathrm{p}<0.01$ compared with the NC group. 

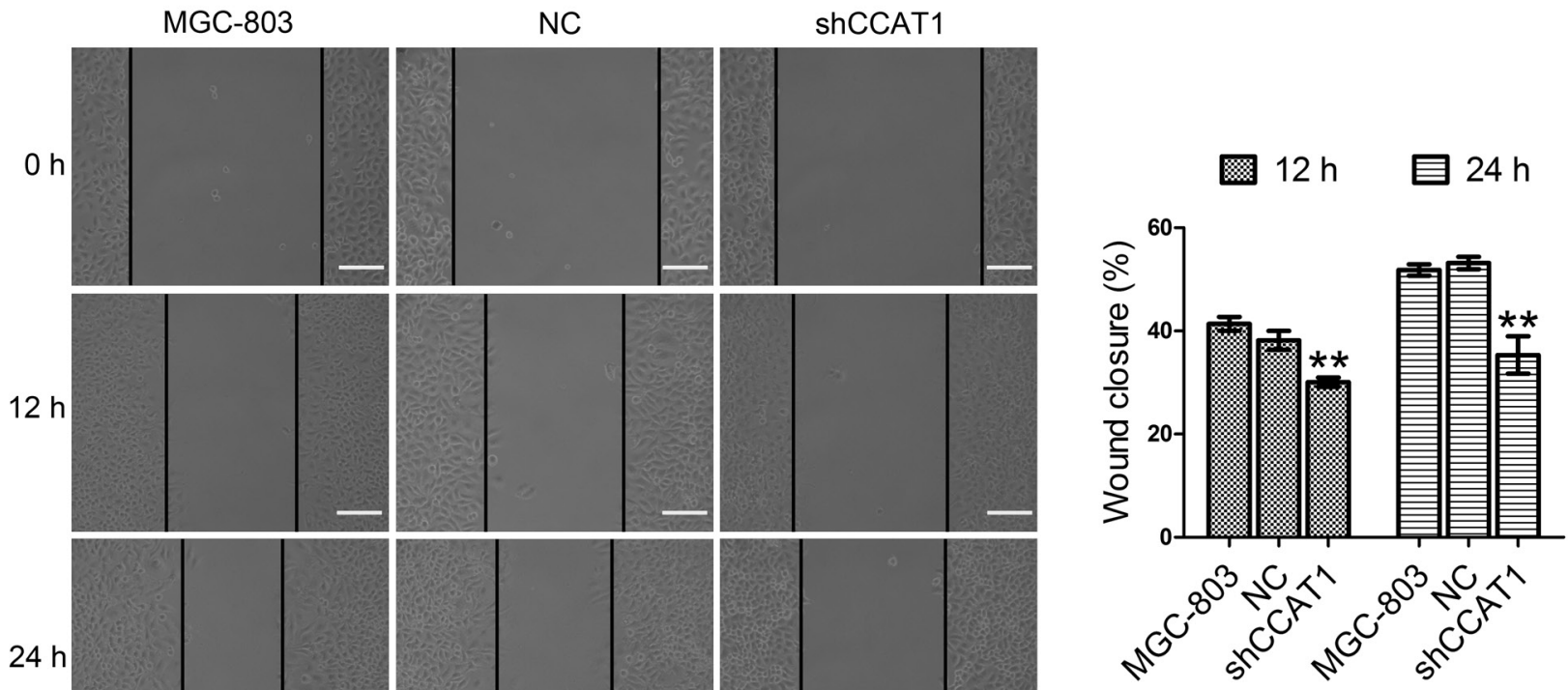

$24 \mathrm{~h}$
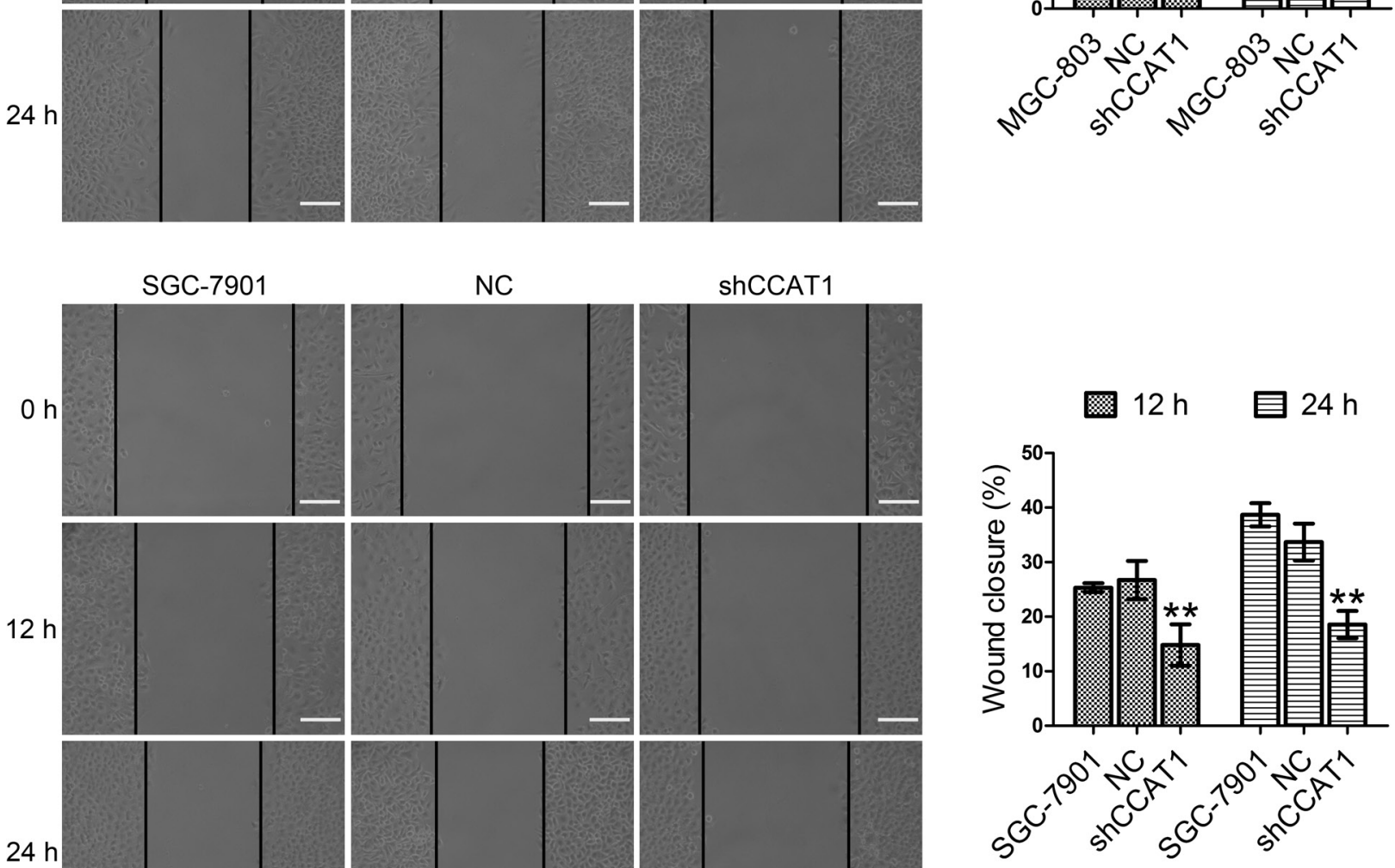

$24 \mathrm{~h}$

$12 \mathrm{~h}$
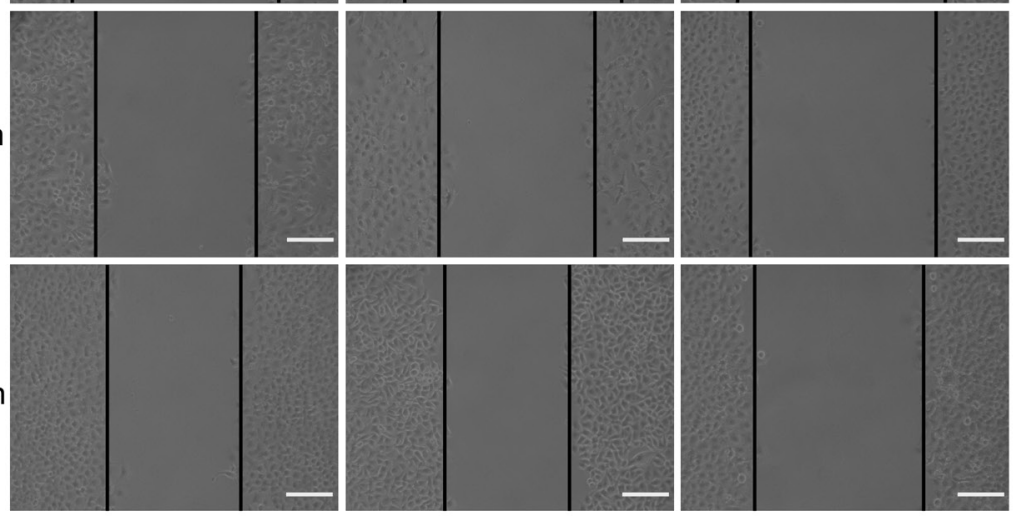

Figure 3. CCAT1 knockdown inhibits GC cell migration. The shRNA-transfected cells were subjected to wound healing assay and wound closure (\%) was calculated. Scale bar $200 \mu \mathrm{m}$. Data is presented as the mean $\pm S D, n=3$. ${ }^{*}<0.05$ and ${ }^{* *} p<0.01$ compared with the NC group.

decreased levels of cyclin B, D1 and E (Figure 2B). This suggests that CCAT1 knockdown inhibits cell proliferation and induces G0/G1 cell cycle arrest in GC cells.

CCAT1 knockdown inhibits GC cell migration and invasion. Wound healing assay and Transwell invasion assay were performed after shCCAT1 transfection to further confirm whether CCAT1 knockdown affected GC cell migration and invasion. Transfection of shCCAT1 led to impaired migration (at 12 and $24 \mathrm{~h}$, as shown in Figure 3) and invasive capability compared to NC-transfected cells (Figure 4); thus suggesting that knockdown of CCAT1 inhibits GC cell migration and invasion.

CCAT1 knockdown decreases Bmi-1 expression in GC cells. Bmi-1 plays an important role in invasion and metastasis of human cancers $[17,18]$. This study investigated whether in vitro CCAT1 knockdown affected Bmi-1 expres- 
sion in GC metastasis. Bmi-1 levels were measured by both RT-qPCR and western blotting. The results showed that shCCAT1 transfection notably decreased Bmi-1 expression at both mRNA (Figure 5A) and protein levels (Figure 5B) in MGC-803 and SGC-7901 cells. This suggests that CCAT1 knockdown regulates GC cell migration and invasion through modulating Bmi-1 expression.
CCAT1 knockdown inhibits peritoneal metastasis of GC in vivo. To investigate whether CCAT1 knockdown inhibited peritoneal metastasis of GC in vivo, SGC-7901 cells transfected with shCCAT1 or NC were administered into BALB/c nude mice by peritoneal injection $\left(1.6 \times 10^{7}\right.$ cells/mouse). The mice were sacrificed five weeks later, and we found that the numbers of nodules in the mesentery and peritoneal walls

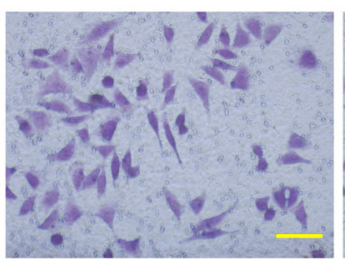

MGC-803

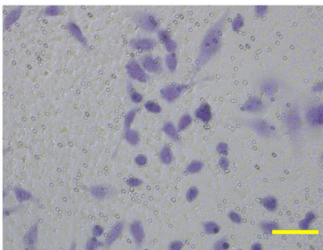

SGC-7901

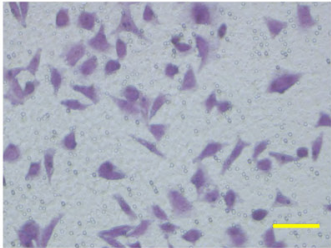

NC

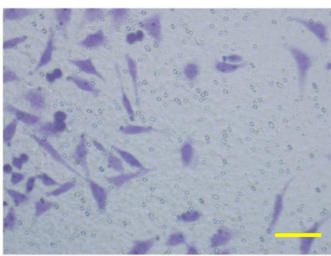

NC

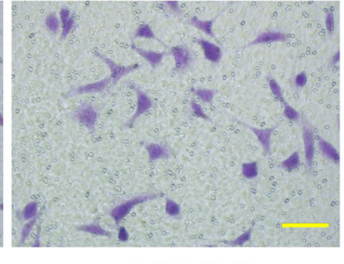

shCCAT1

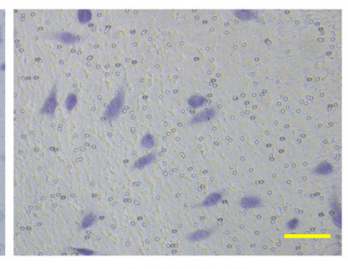

shCCAT1
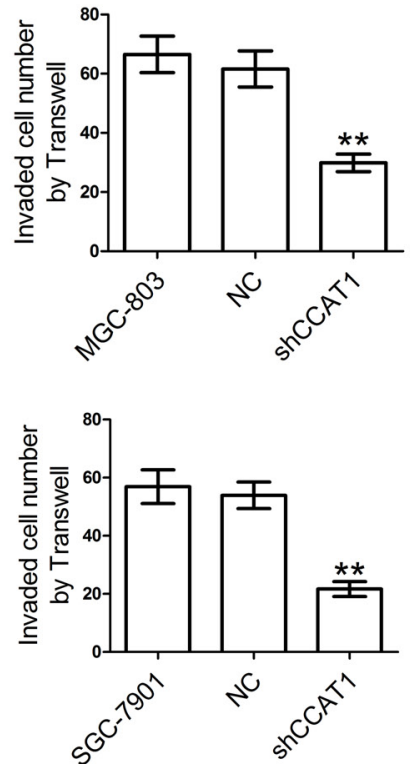

Figure 4. CCAT1 knockdown inhibits GC cell invasion. The shRNA-transfected cells were subjected to Transwell invasion assay. The invaded cell numbers were counted. Scale bar $100 \mu \mathrm{m}$. Data is presented as the mean $\pm S D, n=3$. ${ }^{*}<<0.05$ and ${ }^{* *} p<0.01$ compared with the NC group.

A
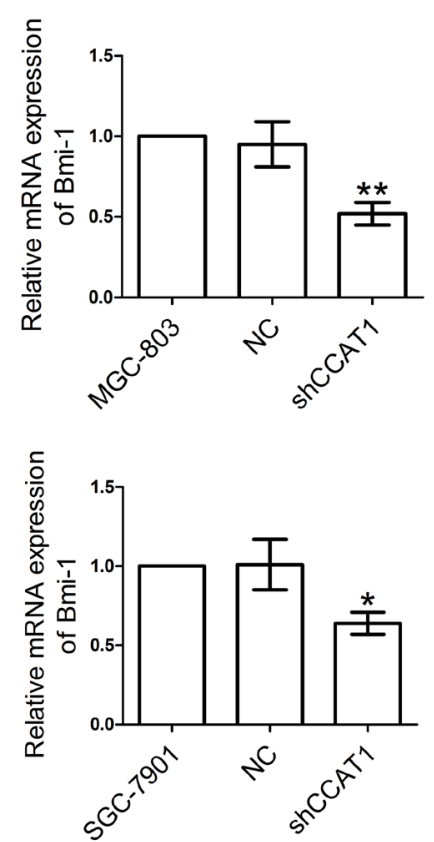

B
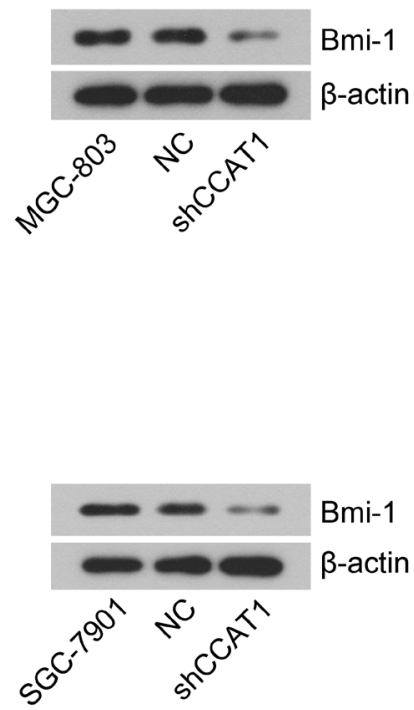
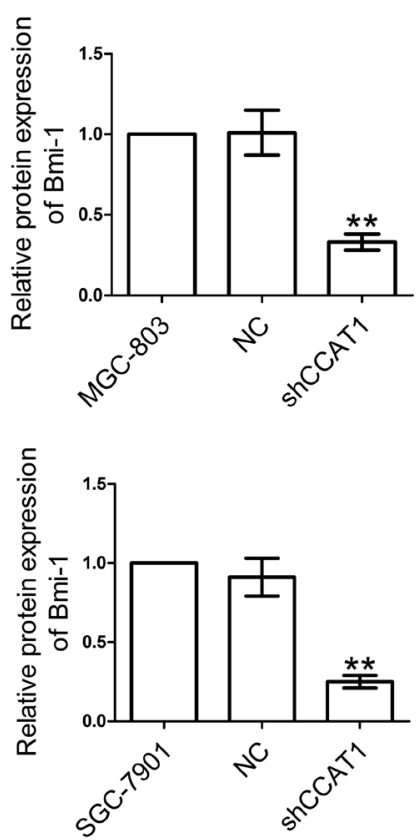

Figure 5. Bmi-1 expression is down-regulated in shCCAT1-transfected cells. A) Bmi-1 expression levels were detected by RT-qPCR in MGC-803 and SGC-7901 cells transfected with shCCAT1 or NC. $\beta$-actin served as internal control. B) Measurement of Bmi- 1 expression by western blotting. $\beta$-actin served as internal control. Data is presented as the mean $\pm \mathrm{SD}, \mathrm{n}=3 .{ }^{*} \mathrm{p}<0.05$ and ${ }^{* *} \mathrm{p}<0.01$ compared with the NC group. 
were significantly lower in the shCCAT1 group than those in the NC group (Figure 6A). We also found that Bmi-1 levels were greatly down-regulated in the tumor tissues of the shCCAT1 group compared to the NC group (Figure 6B and $\mathrm{C})$; thus indicating that CCAT1 affects peritoneal metastasis of GC through Bmi-1.

\section{Discussion}

LncRNA CCAT1 plays a vital role in the pathogenesis of many cancers $[16,19]$. However, the biological functions of CCAT1 in the development of GC remain poorly understood. This study therefore investigated CCAT1's role in GC progression and distant metastasis in vitro and in vivo.

Previous studies revealed that CCAT1 knockdown reduces cell viability in various cancers, including renal cell carcinoma, glioma, melanoma and retinoblastoma [16, 20-22]. Herein, CCAT1 expression was knocked down in two GC cell lines and the effects of CCAT1 knockdown on cell viability, colony formation ability and cell cycle progression were investigated. As expected, the results showed that CCAT1 knockdown significantly reduced MGC-803 and SGC-7901 cell viability and colony formation ability. [23].
Cyclins regulate the eukaryotic cell cycle by forming complexes with cyclin dependent kinases (CDKs) and this complex can result in abnormal cell growth [24, 25]; thus further confirming that cell cycle interruption is one of the hallmarks of cancer cells. Several previous studies have reported that CCAT1 silencing suppresses cell proliferation and causes cell cycle arrest in medulloblastoma, retinoblastoma and pancreatic cancer $[10,22,26]$. Herein, we consistently found that CCAT1 knockdown arrested the cell cycle at G0/G1 phase and this resulted in significant decrease in cyclin $\mathrm{B}, \mathrm{D} 1$ and E levels compared to the NC group. Interestingly, we also found that CCAT1 knockdown decreased the fraction of MGC-803 cells in the S phase and reduced SGC-7901 cell proportion in the $\mathrm{G} 2 / \mathrm{M}$ phase. The cyclin D-CDK4/6 and cyclin $\mathrm{E}-\mathrm{CDK} 2$ complexes regulate $\mathrm{G} 1$ to $\mathrm{S}$ phase progression, while the cyclin $\mathrm{B}-\mathrm{CDK} 1$ complex regulates progression from the G2 to $M$ phase [23]. These interesting findings suggest that regulation of cell cycle progression by CCAT1 knockdown is slightly different in MGC-803 and SGC-7901 cells, and this may be associated with the balance between cyclin D1/E and cyclin B. Further, all results highlight that CCAT1 knockdown inhibited cell proliferation by modulating cell cycle progression and cell cycle-related proteins.

A

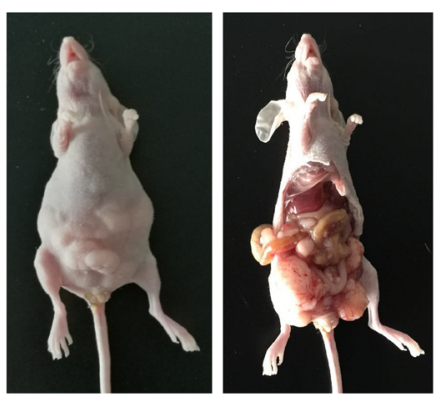

NC

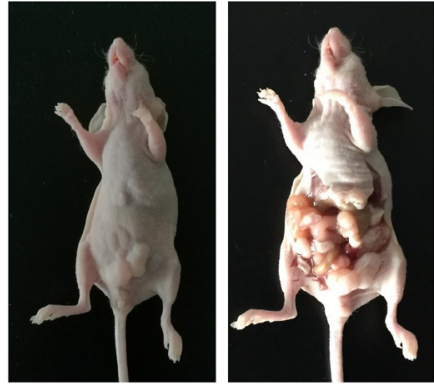

shCCAT1
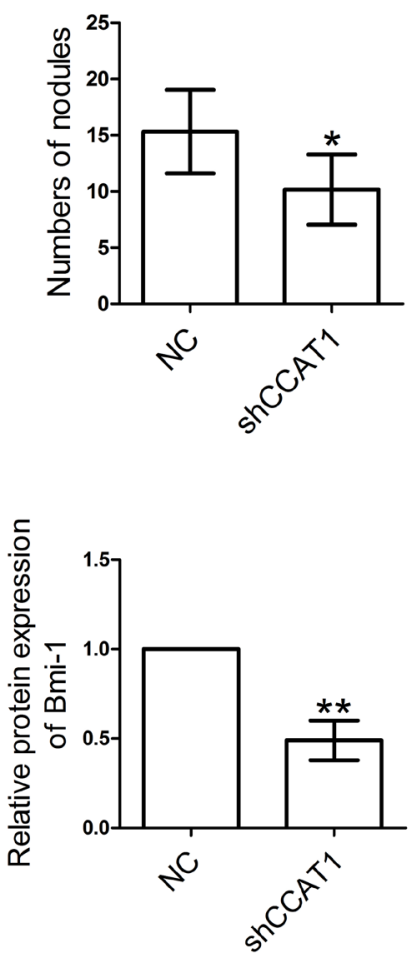

Figure 6. CCAT1 knockdown suppresses peritoneal metastasis and reduces Bmi-1 expression in nude mice. A) SGC-7901 cells transfected with shCCAT1 or NC were peritoneally injected $\left(200 \mu \mathrm{l}, 8 \times 10^{7}\right.$ cells $\left./ \mathrm{ml}\right)$ into the nude mice and the mice were sacrificed 35 days later and the number of nodules in the mesentery and peritoneal walls was counted. B) Bmi-1 expression in peritoneal tumor tissues was measured by RT-qPCR. C) Western blotting was performed to determine $\mathrm{Bmi}-1$ expression in peritoneal tumor tissues. $\boldsymbol{\beta}$-actin served as internal control, and data is presented as the mean $\pm \mathrm{SD}$, $\mathrm{n}=6 .{ }^{*} \mathrm{p}<0.05$ and ${ }^{* *} \mathrm{p}<0.01$ compared with the NC group. 
Cell migration and invasion are also critical factors in tumor metastasis [27]. Zhang et al. demonstrated that high CCAT1 expression closely correlates with TNM stage, differentiation grade and lymph node metastasis in breast cancer patients [28], and Zhu et al. reported that CCAT1 is a potential biomarker for predicting prognosis in patients with hepatocellular carcinoma. [29]. Although CCAT1 knockdown inhibits cell migration and/or invasion in glioma, melanoma, hepatocellular carcinoma, retinoblastoma and pancreatic cancer [10, $16,21,22,30]$, few reports have mentioned the role of CCAT1 in GC metastasis. Our in vitro studies consistently showed that CCAT1 knockdown suppressed migration and invasion of GC cells. We then performed an in vivo study using BALB/c nude mice to investigate the role of CCAT1 in GC peritoneal metastasis, and results highlighted that the nude mice injected with SGC-7901-shCCAT1 cells had less nodules in the mesentery and peritoneal walls than the mice in the NC group. These results suggest that CCAT1 knockdown inhibits invasion and metastasis of GC both in vitro and in vivo.

The Bmi-1 gene was initially identified by van Lohuizen et al. [31] in 1991, and Bmi-1 is up-regulated in multiple cancers and correlates with poor prognosis of cancer patients; especially those with gastric carcinoma, breast cancer, nasopharyngeal carcinoma and esophageal squamous cell carcinoma [18, 32, 33]. In addition, Liu et al. [34] found that down-regulated Bmi-1 inhibits epithelial-mesenchymal transition (EMT) and invasion of melanoma cells, and Wang et al. [17] demonstrated that Bmi-1 knockdown decreases the invasiveness of pancreatic cancer stem cells and reduces liver metastasis capacity in nude mice.

The foregoing studies suggest that Bmi-1 is associated with cancer cell metastasis, and while authors have reported that Bmi-1 is associated with GC progression [35-37], only the following two articles report correlation between CCAT1 and Bmi-1 in cancer progression. Ma et al. [38] revealed that CCAT1 knockdown inhibits proliferation and invasion of gallbladder cancer cells partly through miR-218-5p-mediated regulation of Bmi-1 and $\mathrm{Lu}$ et al. [39] found that CCAT1 modulates Bmi-1 expression and cell cycle progression through negative regulation of miR-218 in human bronchial epithelial cells exposed to cigarette smoke extract. Therefore, we speculate that CCAT1 mediates GC metastasis via Bmi-1 expression, and our results highlighting that CCAT1 knockdown significantly reduces Bmi-1 expression in both GC cell lines and the tumor tissues of peritoneal metastasis models suggests Bmi-1 involvement in GC metastasis. As previously demonstrated $[38,39]$, CCAT1 regulates Bmi-1 expression through miRNAs in GC metastasis, but the precise mechanism requires further investigation.

In conclusion; herein we provide evidence that CCAT1 affects GC cell proliferation, migration and invasion and modulates peritoneal metastasis via Bmi-1. Long non-coding RNA colon cancer-associated transcript 1 (lncRNA CCAT1) may therefore serve as a potential therapeutic target for GC patients.

\section{References}

[1] LUO G, HU Y, ZHANG Z, WANG P, LUO Z et al. Clinicopathologic significance and prognostic value of Ki-67 expression in patients with gastric cancer: a meta-analysis. Oncotarget 2017; 8: 50273-50283. https://doi.org/10.18632/ oncotarget. 17305

[2] PIAZUELO MB, CORREA P. Gastric cancer: Overview. Colomb Med (Cali) 2013; 44: 192-201.

[3] ARMERO VES, TREMBLAY MP, ALLAIRE A, BOUDREAULT S, MARTENON-BRODEUR C et al. Transcriptome-wide analysis of alternative RNA splicing events in Epstein-Barr virus-associated gastric carcinomas. PLoS One 2017; 12: e0176880. https://doi.org/10.1371/journal. pone. 0176880

[4] FERLAY J, SOERJOMATARAM I, DIKSHIT R, ESER S, MATHERS $\mathrm{C}$ et al. Cancer incidence and mortality worldwide: sources, methods and major patterns in GLOBOCAN 2012. Int J Cancer 2015; 136: E359-E386. https://doi. org/10.1002/ijc. 29210

[5] ZHOU X, ZHU W, LI H, WEN W, CHENG W et al. Diagnostic value of a plasma microRNA signature in gastric cancer: a microRNA expression analysis. Sci Rep 2015; 5: 11251. https://doi.org/10.1038/srep11251

[6] MILLER CR, RUPPERT AS, FOBARE S, CHEN TL, LIU C et al. The long noncoding RNA, treRNA, decreases DNA damage and is associated with poor response to chemotherapy in chronic lymphocytic leukemia. Oncotarget 2017; 8: 2594225954. https://doi.org/10.18632/oncotarget.15401

[7] QI F, LIU X, WU H, YU X, WEI C et al. Long noncoding AGAP2-AS1 is activated by SP1 and promotes cell proliferation and invasion in gastric cancer. J Hematol Oncol 2017; 10: 48. https://doi.org/10.1186/s13045-017-0420-4

[8] MALEK E, JAGANNATHAN S, DRISCOLL JJ. Correlation of long non-coding RNA expression with metastasis, drug resistance and clinical outcome in cancer. Oncotarget 2014; 5: 8027-8038. https://doi.org/10.18632/oncotarget.2469

[9] LU L, YU X, ZHANG L, DING X, PAN H et al. The long noncoding RNA RHPN1-AS1 promotes uveal melanoma progression. Int J Mol Sci 2017;18: E26. https://doi.org/10.3390/ ijms 18010226

[10] YU Q, ZHOU X, XIA Q, SHEN J, YAN J et al. Long non-coding RNA CCAT1 that can be activated by c-Myc promotes pancreatic cancer cell proliferation and migration. Am J Transl Res 2016; 8: 5444-5454.

[11] ALAIYAN B, ILYAYEV N, STOJADINOVIC A, IZADJOO $M$, ROISTACHER $M$ et al. Differential expression of colon cancer associated transcript1 (CCAT1) along the colonic adenoma-carcinoma sequence. BMC Cancer 2013; 13: 196. https://doi.org/10.1186/1471-2407-13-196.

[12] MIZRAHI I, MAZEH H, GRINBAUM R, BEGLAIBTER N, WILSCHANSKI $\mathrm{M}$ et al. Colon Cancer Associated Transcript-1 (CCAT1) Expression in Adenocarcinoma of the Stomach. J Cancer 2015; 6: 105-110. https://doi.org/10.7150/ jca. 10568

[13] ZHU H, ZHOU X, CHANG H, LI H, LIU F et al. CCAT1 promotes hepatocellular carcinoma cell proliferation and invasion. Int J Clin Exp Pathol 2015; 8: 5427-5434. 
[14] JIANG XM, LI ZL, LI JL, ZHENG WY, LI XH et al. LncRNA CCAT1 as the unfavorable prognostic biomarker for cholangiocarcinoma. Eur Rev Med Pharmacol Sci 2017; 21: 1242-1247.

[15] YANG F, XUE X, BI J, ZHENG L, ZHI K et al. Long noncoding RNA CCAT1, which could be activated by c-Myc, promotes the progression of gastric carcinoma. J Cancer Res Clin Oncol 2013; 139: 437-445. https://doi.org/10.1007/ s00432-012-1324-x

[16] CUI B, LI B, LIU Q, CUI Y. IncRNA CCAT1 promotes glioma tumorigenesis by sponging miR-181b. J Cell Biochem 2017; 118: 4548-4557. https://doi.org/10.1002/jcb.26116

[17] WANG MC, JIAO M, WU T, JING L, CUI J et al. Polycomb complex protein BMI-1 promotes invasion and metastasis of pancreatic cancer stem cells by activating PI3K/AKT signaling, an ex vivo, in vitro, and in vivo study. Oncotarget 2016; 7: 9586-9599. https://doi.org/10.18632/oncotarget.7078

[18] GUOBH, FENG Y,ZHANG R, XU LH, LI MZet al. Bmi-1 promotes invasion and metastasis, and its elevated expression is correlated with an advanced stage of breast cancer. Mol Cancer 2011; 10: 10. https://doi.org/10.1186/1476-4598-10-10

[19] ARUNKUMAR G, MURUGAN AK, PRASANNA SRINIVASA RAO H, SUBBIAH S, RAJARAMAN R et al. Long noncoding RNA CCAT1 is overexpressed in oral squamous cell carcinomas and predicts poor prognosis. Biomed Rep 2017; 6: 455-462. https://doi.org/10.3892/br.2017.876

[20] CHEN S, MA P, LI B, ZHU D, CHEN X et al. LncRNA CCAT1 inhibits cell apoptosis of renal cell carcinoma through upregulation of Livin protein. Mol Cell Biochem 2017; 434: 135-142. https://doi.org/10.1007/s11010-017-3043-8

[21] LV L, JIA JQ, CHEN J. LncRNA CCAT1 upregulates proliferation and invasion in melanoma cells via suppressing miR33a. Oncol Res 2018; 26: 201-208. https://doi.org/10.3727/0 96504017X14920318811749

[22] ZHANG H, ZHONG J, BIAN Z, FANG X, PENG Y et al. Long non-coding RNA CCAT1 promotes human retinoblastoma SO-RB50 and Y79 cells through negative regulation of miR-218-5p. Biomed Pharmacother 2017; 87: 683-691. https://doi.org/10.1016/j.biopha.2017.01.004

[23] STEWART ZA, WESTFALL MD, PIETENPOL JA. Cellcycle dysregulation and anticancer therapy. Trends Pharmacol Sci 2003; 24: 139-145. https://doi.org/10.1016/S01656147(03)00026-9

[24] STAMATAKOS M, PALLA V, KARAISKOS I, XIROMERITIS K, ALEXIOU I et al. Cell cyclins: triggering elements of cancer or not? World J Surg Oncol 2010; 8: 111. https://doi. org/10.1186/1477-7819-8-111

[25] LEE JI, KIM IH, NAM TJ. Crude extract and solvent fractions of Calystegia soldanella induce G1 and S phase arrest of the cell cycle in HepG2 cells. Int J Oncol 2017; 50: 414-420. https://doi.org/10.3892/ijo.2017.3836

[26] GAO R, ZHANG R, ZHANG C, ZHAO L, ZHANG Y. Long noncoding RNA CCAT1 promotes cell proliferation and metastasis in human medulloblastoma via MAPK pathway. Tumori 2018; 104: 43-50. https://doi.org/10.5301/tj.5000662

[27] ZHANG M, GAO C, YANG Y, LI G, DONG J et al. MiR-424 promotes non-small cell lung cancer progression and metastasis through regulating the tumor suppressor gene TNFAIP1. Cell Physiol Biochem 2017; 42: 211-221. https://doi. org/10.1159/000477314
[28] ZHANG XF, LIU T, LI Y, LI S. Overexpression of long noncoding RNA CCAT1 is a novel biomarker of poor prognosis in patients with breast cancer. Int J Clin Exp Pathol 2015; 8: 9440-9445.

[29] ZHU HQ, ZHOU X, CHANG H, LI HG, LIU FF et al. Aberrant expression of CCAT1 regulated by c-Myc predicts the prognosis of hepatocellular carcinoma. Asian Pac J Cancer Prev 2015; 16: 5181-5185.

[30] DOU C, SUN L, JIN X, HAN M, ZHANG B et al. Long non-coding RNA colon cancer-associated transcript 1 functions as a competing endogenous RNA to regulate cyclin-dependent kinase 1 expression by sponging miR-490-3p in hepatocellular carcinoma progression. Tumour Biol 2017; 39: 1010428317697572. https://doi. org/10.1177/1010428317697572

[31] VAN LOHUIZEN M, VERBEEK S, SCHEIJEN B, WIENTJENS E, VAN DER GULDEN H et al. Identification of cooperating oncogenes in E mu-myc transgenic mice by provirus tagging. Cell 1991; 65: 737-752.

[32] YANG DD, CUI BB, SUN LY, ZHENG HQ, HUANG Q et al. The co-expression of USP22 and BMI-1 may promote cancer progression and predict therapy failure in gastric carcinoma. Cell Biochem Biophys 2011; 61: 703-710. https://doi. org/10.1007/s12013-011-9229-x

[33] SONG LB, ZENG MS, LIAO WT, ZHANG L, MO HY et al. Bmi-1 is a novel molecular marker of nasopharyngeal carcinoma progression and immortalizes primary human nasopharyngeal epithelial cells. Cancer Res 2006; 66: 6225-6232. https://doi.org/10.1158/0008-5472.CAN-06-0094

[34] LIU Y, CHU Z, LI Q, PENG B, XU S et al. Downregulation of Bmi-1 suppresses epithelialmesenchymal transition in melanoma. Oncol Rep 2017; 37: 139-146. https://doi. org/10.3892/or.2016.5244

[35] WU C, ZHENG X, LI X, FESLER A, HU W et al. Reduction of gastric cancer proliferation and invasion by miR-15a mediated suppression of Bmi-1 translation. Oncotarget 2016; 7: 14522-14536. https://doi.org/10.18632/oncotarget.7392

[36] YU WW, JIANG H, ZHANG CT, PENG Y. The SNAIL/miR128 axis regulated growth, invasion, metastasis, and epithelial-to-mesenchymal transition of gastric cancer. Oncotarget 2017; 7: 39280-39295. https://doi.org/10.18632/oncotarget.16849

[37] GAO FL, LI WS, LIU CL, ZHAO GQ. Silencing Bmi-1 enhances the senescence and decreases the metastasis of human gastric cancer cells. World J Gastroenterol 2013; 19: 8764-8769. https://doi.org/10.3748/wjg.v19.i46.8764

[38] MA MZ, CHU BF, ZHANG Y, WENG MZ, QIN YY et al. Long non-coding RNA CCAT1 promotes gallbladder cancer development via negative modulation of miRNA-218-5p. Cell Death Dis 2015; 6: e1583. https://doi.org/10.1038/cddis. 2014.541

[39] LU L, XU H, LUO F, LIU X, LU X et al. Epigenetic silencing of miR-218 by the lncRNA CCAT1, acting via BMI1, promotes an altered cell cycle transition in the malignant transformation of HBE cells induced by cigarette smoke extract. Toxicol Appl Pharmacol 2016; 304: 30-41. https://doi.org/10.1016/j. taap.2016.05.012 


\section{Knockdown of long non-coding RNA PEG10 inhibits growth, migration and invasion of gastric carcinoma cells by up-regulating miR-3200}

J. WANG*, X. Q. CHU*, D. ZHANG, D. F. KONG*

Supplemental Material
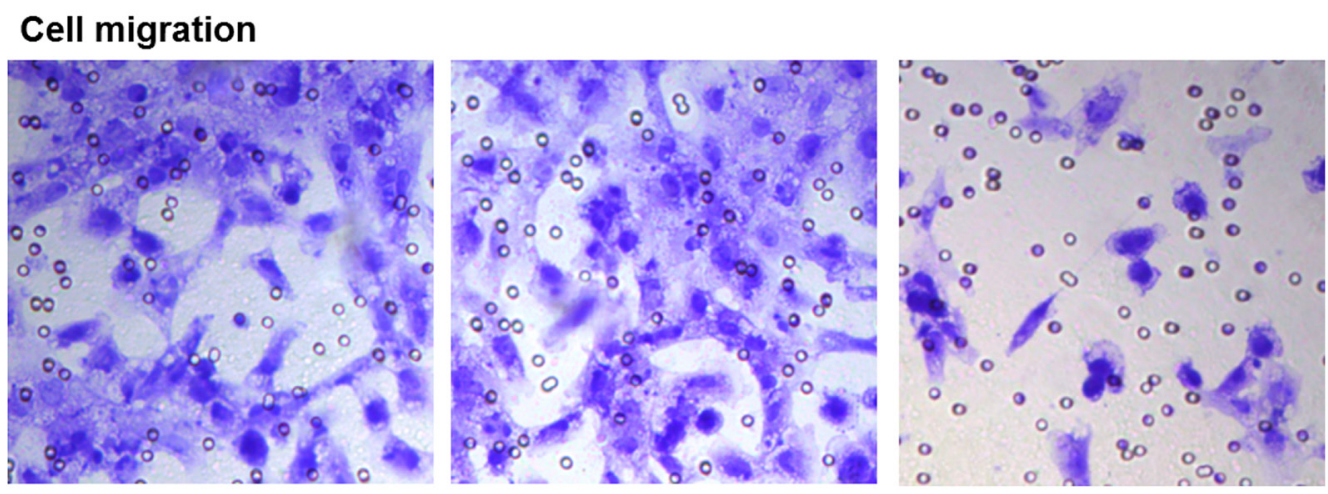

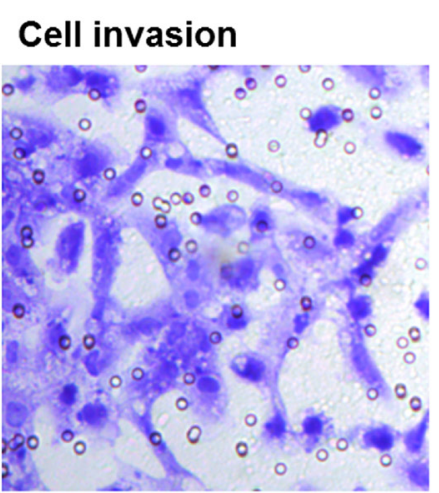

Control

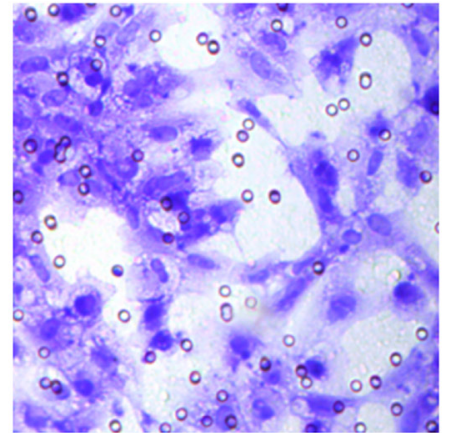

shNC

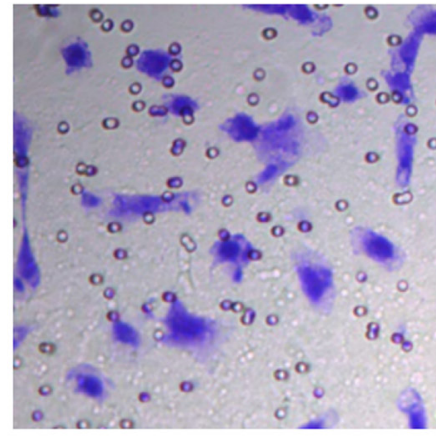

sh-PEG10 \#2

Supplementary Figure 1. Cell migration and invasion images after transfection with shNC and sh-PEG10 \#2.

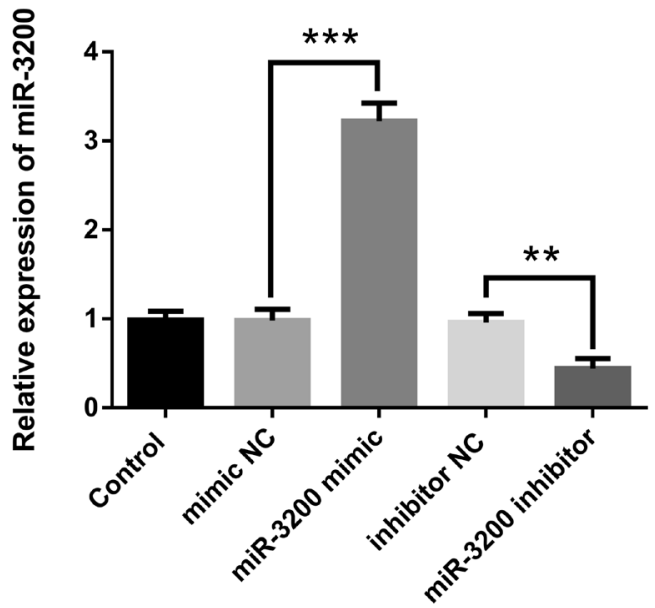

Supplementary Figure 2. Transfection efficiency of miR-3200 in NCI-N87 cells after transfection with miR-3200 mimic or inhibitor. Data is expressed as mean \pm SD. ${ }^{\star *} \mathrm{p}<0.01,{ }^{* *} \mathrm{p}<0.001$. 

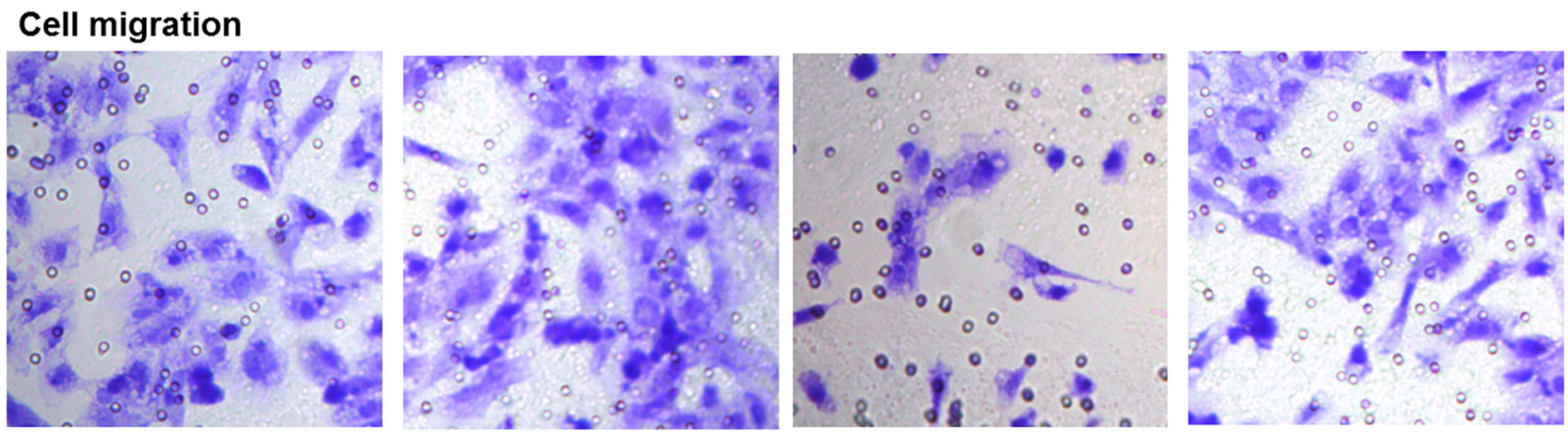

\section{Cell invasion}

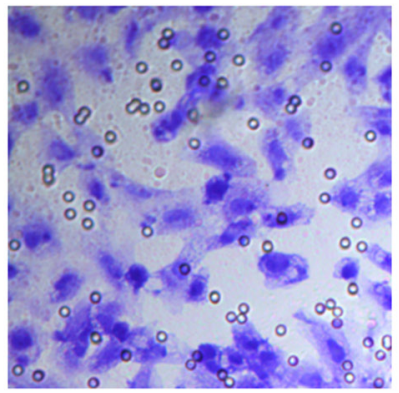

Control

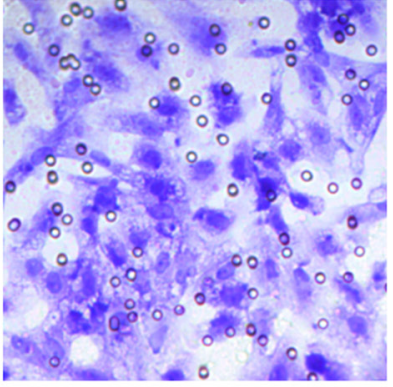

shNC+inhibitor NC

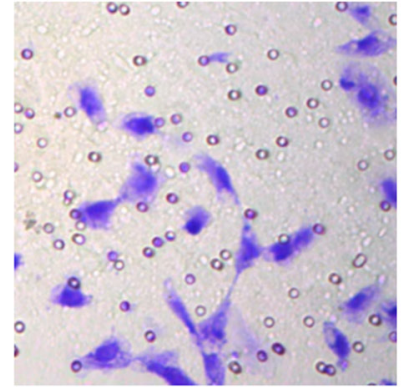

sh-PEG10 \#2+ inhibitor NC

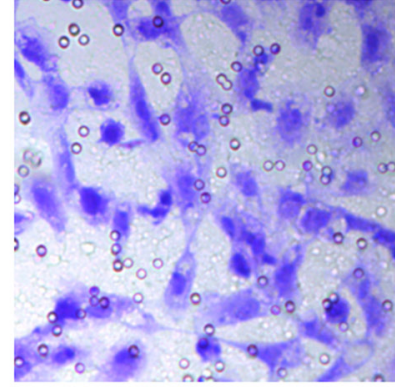

sh-PEG10 \#2+ miR-3200 inhibitor

Supplementary Figure 3. Cell migration and invasion images after transfection with sh-PEG10 \#2 and miR-3200 inhibitor.
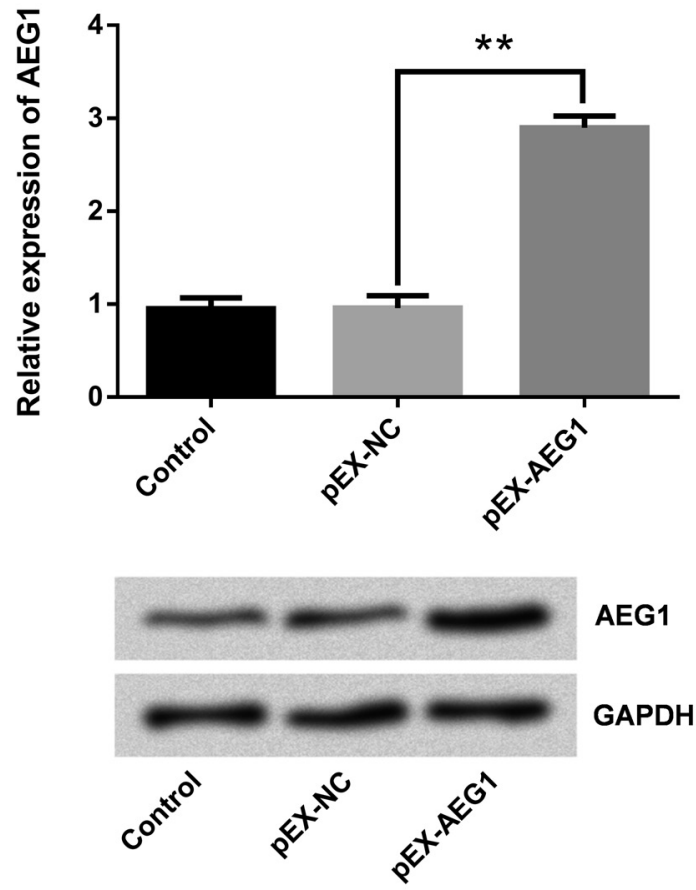

Supplementary Figure 4. Transfection efficiency of AEG1 in NCI-N87 cells after transfection with pEX-AEG1. Data is expressed as mean \pm SD. ${ }^{* *} \mathbf{p}<0.01$. 

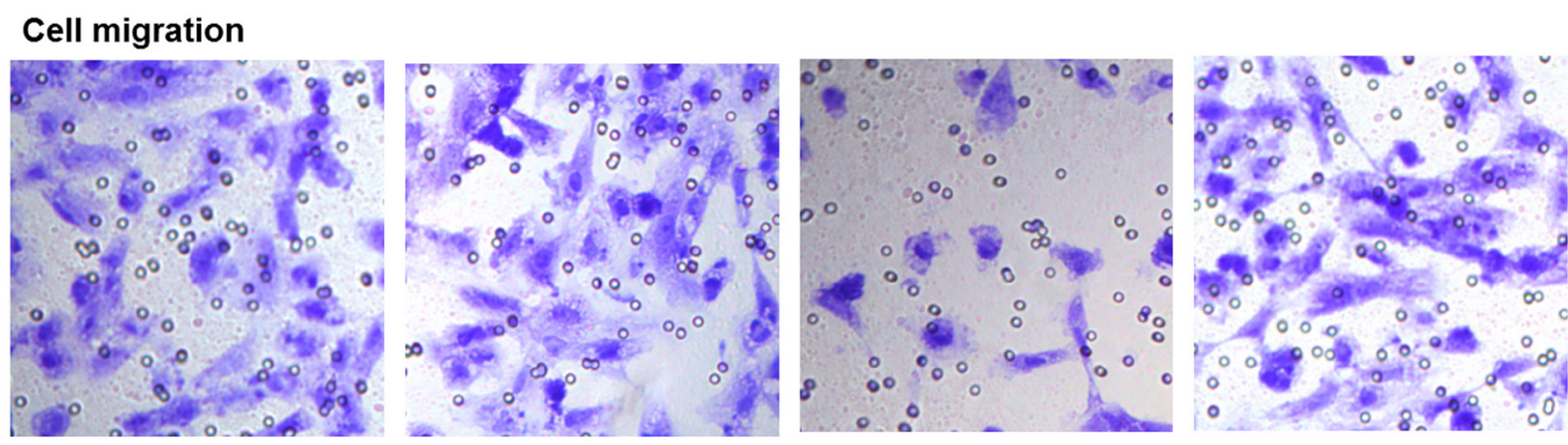

\section{Cell invasion}

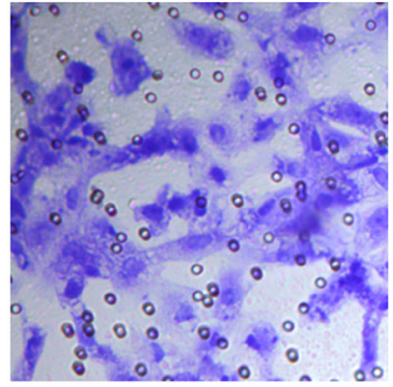

Control

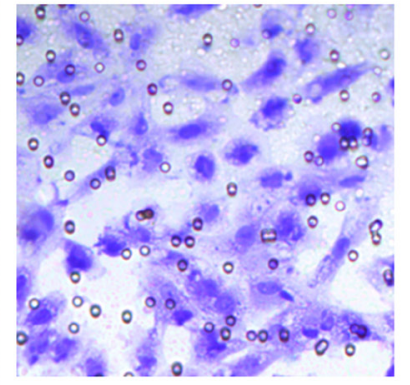

mimic NC+pEX-NC

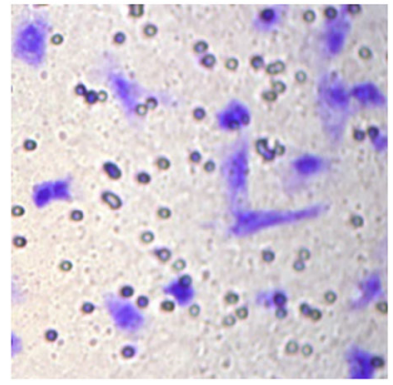

miR-3200 mimic $+p E X-N C$

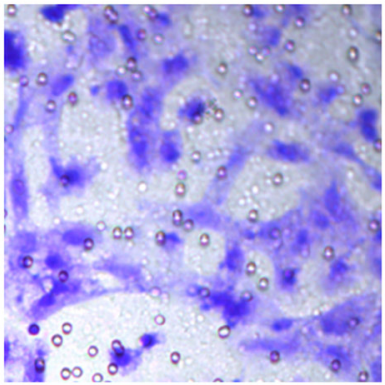

miR-3200

mimic + pEX-AEG1

Supplementary Figure 5. Cell migration and invasion images after transfection with miR-3200 mimic and pEX-AEG1. 